\title{
TÓDOR KÁRMÁN - WORK OF A HUNGARIAN INVENTOR
}

\author{
József GÁTI, ${ }^{1}$ Rebeka OSVÁTH, ${ }^{2}$ János KUTI ${ }^{3}$ \\ Óbuda University, Budapest, Hungary \\ ${ }^{1}$ gati@uni-obuda.hu \\ ${ }^{2}$ rebeka.osvath@gmail.com \\ ${ }^{3}$ kuti.janos@rh.uni-obuda.hu
}

\begin{abstract}
Sadly, many great Hungarian engineers have been forgotten, engineers who could be outstanding role models for the young engineers of today. In some aspects Tódor Kármán belongs to these forgotten engineers. For that reason, we examine his life and work in our research. I distinctly refer to the educational system of the era, since his scientific work also originated from this. This essay also explores the most important work and inventions of the great scientist with regard to his space research activities that were way ahead of his time. In this context, I also mention Dr. Antal Bejczy, one of his followers in space research.
\end{abstract}

Keywords: history of technology, biography, hungarian inventor.

\section{The Family of Tódor Kármán}

Tódor Kármán was born in Budapest on 11th May, 1881, as the third child of the Kármán family.

The lineage of his mother Helen Kohn (or Ilka Kohn according to the records of the National Educational Library and Museum) can be traced back to the great mathematician of the imperial court of Prague, who invented the first mechanical robot, the Golem.

His father, Mór Kármán was born in 1843 to a Jewish family in Szeged. Lipót Lőw rabbi urged him to study and become a rabbi. However, Mór considered studying more important than religion, thus he went to the University of Vienna in order to study philosophy. After he graduated, he returned to Hungary and made his doctoral degree there. In 1869, he travelled to Leipzig to study the German educational system following the advice of the Hungarian educational minister, Baron József Eötvös.

Mór Kármán advised a three-year curriculum following the German and French examples, with the aim not just to unify, but also to transfer the organization of education from the church to the state. Meanwhile, Baron József Eötvös passed away but his successor Tódor Pauler was also deeply influenced by innovative ideas, thus Mór Kármán became later the secretary general of the
National Educational Council which continued to elaborate the reorganization. As a result of his successes, he was offered a job at the imperial court; he had to plan the education of Franz Joseph's nephew, Archduke Albrecht. At this time the emperor bestowed on him a noble title as an acknowledgement of his work. For the noble title he needed to own land, and there was only a little vineyard in the family property, so for this reason the noble forename of the family became "von Szőlőskislak”.

Tódor Kármán was educated by a private tutor in the person of Dr. Málnai, one of the former students of his father. He studied literature, history and geography. In his childhood he proved to be very talented in mental arithmetic, at various family gatherings he was often asked to add up or subtract large numbers, and he always accomplished the tasks without any mistakes. Although he was interested in mathematics, he was kept from it until his teens at the request of his father, who did not want him to become a prodigy. According to Mór Kármán’s principles, the children in the family had to learn from teaching, thus the oldest brother Elemér taught Feri, who was next in line, and Feri later became Tódor's teacher. Their sister, Pipő, was the youngest sibling, she was taught by all of them. 


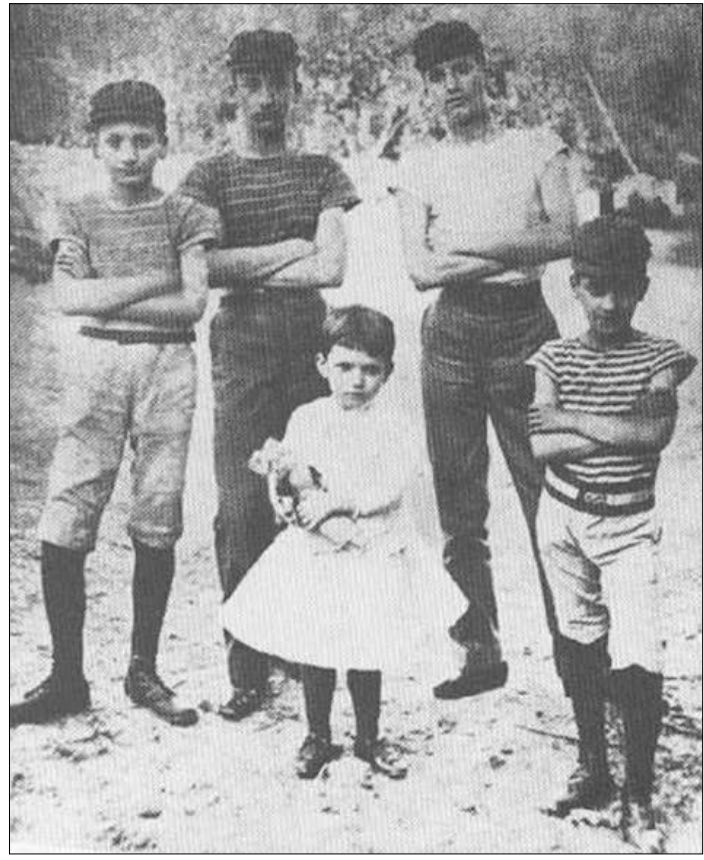

Figure 1. The Kármán children, Tódor is on left

Tódor was enrolled to the training school in Trefort Street when he was 9 years old. The "sample" grammar school was founded by his father; it was operating on the basis of his educational principles.

According to Mór Kármán, the secret of effective education was that the students should learn the subjects by realizing their utility and experiencing the connection of the sciences to ordinary life.

For instance during mathematics lessons in the subject of statistics, they gathered data from Hungarian crop production, and made diagrams and charts of it.

They never studied rules word for word; they tried to understand them by deduction. The children were trained to learn the logic instead.

In Hungary, the sample grammar school was the first where university students were teachers as well. The secondary school students competed with each other for the Eötvös Prize every year. By this prize those students were rewarded who excelled in maths and in natural sciences. The prize was a great acknowledgement not only for the student, but also for the preparatory teacher. Tódor Kármán also competed for the prize and he won it. In his scientific work, the knowledge and confidence he obtained from the sample grammar school was quite fundamental.

\section{Academic Years}

Tódor Kármán enrolled to the Joseph University of Technology and Economics in 1889. The maths lectures were close to his heart, but within mathematics he liked descriptive geometry the most. He also studied literature and history for some semesters, sometimes he even took a fancy to writing poems as well. However, he neglected the study of economics. During his academic years Professor Donát Bánki played an enormous role. He was not the only one in the family who had a good relationship with his favourite teacher, but his father was also the professor's good friend. His first technical publication was published with Bánki's help. He was searching for the solution for a problem occurring in the engine. The exact question of his research was: "Why do the valves sometimes oscillate causing a great noise?”. Bánki was so fascinated with his work that he decided that in one of his own books - in which he summarized various studies about technical problems - he would publish Tódor Kármán’s study as well.

In 1902, he graduated from the university "mit Ausreichen" (with a certificate of merit). Later he was enlisted in the Austro-Hungarian army, where he participated in the artillery. At this time he could not have known that in his career, military technology would play an important role. After his time in the service, he returned to the Technical University to be an assistant lecturer to Professor Bánki. In 1905 he started to be interested in the phenomenon of the instability of flexural stiffness. At first Leonhard Euler examined the problem, but his theory was only applicable to fully flexible columns. He published his first results on the topic in the Gazette of the Association of Hungarian Engineers and Architects. In professional circles there was no significant response to his publication, but his father was all the more overwhelmed by it. Mór Kármán encouraged his son to continue his studies abroad.

After due deliberation they chose Germany; Tódor Kármán got a two-year scholarship in Göttingen. Tódor remembered the University of Göttingen as the leading mathematical centre of the world, where among others Planck, Gauss and Hilbert worked as well. Ludwig Prandtl, the directing professor in the physics department of the university, started to be interested in his bending theory. Prandtl promised to purchase a hydraulic press, which would have been necessary for his experiments; however, Tódor waited 
in vain, since there was not any progress in this case. In his desperation he decided to leave Göttingen, since he felt that he attended the lectures without avail, and could not make an advance in his studies. In 1907, he entered the University of Charlottenburg, but he quickly realized that although the institute welcomed him, they did not have the appropriate equipment for his experiments, thus after a short period he went back to the University of Göttingen. The Hydraulic press was eventually built in Göttingen, where Tódor Kármán performed his experiments.

In 1908 he finally finished his doctoral dissertation, which he published in 1909. His scholarship in Göttingen lasted until the winter of 1908. The next milestone in his life was France, namely the Paris-Sorbonne University, where he attended the lectures of Marie Curie among others. He began to be interested in airplanes in France. In particular, he was fascinated in the engines of the airplanes at first, but later he theorized about how aeronautics could be made safer. Considering the engines, he was sure that the secret of the improvement of airplanes lay in reducing the weight of the engines, thus he met some aircraft designers in connection with this issue. Tódor Kármán had not stayed in Paris for long. Prandtl wanted to build a wind tunnel in which they could test the model of an airship. Tódor Kármán was asked to assist in the experiment. Besides aiding in the aerodynamic tests, he was also asked to give lectures about mechanics at the university as a private tutor.

\section{Aeronautical Science}

During one of his travels to Bologna, he noticed a painting in a museum. The painting depicted Saint Christopher as he crossed the water with Jesus at his shoulders. He observed in the painting that behind the legs of the saint the water is whirling from here to there. He contemplated a lot about the cause of the whirls.

At this time Prandtl was studying the extent of the pressure in different points of the surface of circular cylinder placed in a constant speed water stream. He entrusted one of his PhD students with performing the experiments connected with it. The experiments did not give appropriate results. Kármán decided to investigate the issue.

He assumed that the whirls around the cylinder exfoliate from the top and the bottom of the cylinder alternating each other. After examining the motion, he realized that this condition could only be stable if the whirls would not appear in twos at the same time, but as offsets to each other. He became known internationally by this theory in the field of aeronautical science.

By 1912 he had been working as a private tutor in Göttingen for four years, when he applied for the leadership of the Department of Applied Mathematics at the Mining Academy in Selmecbánya founded by Maria Theresa. Kármán offered that he would ask for one-year's leave in order to finish his work in Göttingen.

In 1913 he received an offer from the Department of Aeronautical Science of the Technical College at Aachen, thus he resigned from his position in Selmecbánya. The institute was famous from his metallurgical and mining engineering training. The fact that they also taught aeronautical science was Professor Hugo Junkers' accomplishment, who engaged in the production of aircraft after leaving the university, and thus he became one of Kármán's important clients. Before his leaving, Junker suggested that they should establish a department for aeronautical science. Although the department was founded, besides aeronautical science mechanics had a place as well. After Kármán took up the position at the department, his first mission was to improve the former wind tunnel. He wanted to transform it for the model they had made in Göttingen, since at the German university they had already learned that they achieved better results if they circulated only the air inside the laboratory for the experiments and did not replaced it with fresh air from outside. Thereby the experiments were not affected by the constitution and pollution of the air. The wind tunnel was finished in 1914.

One day Hugo Junkers visited Tódor Kármán, because he wanted to produce an aircraft that was widely different from the canvas covered frames which were being used until then. His aim was that the whole airplane would be made from metal. He asked Kármán to develop a mathematical method with which he could find the most suitable form for the wings. Kármán was at home in Aachen, he built a strong relationship with his colleagues and his students, too. At one time some German pilots asked him to teach them the theory of aeronautics, and they promised him in exchange that they would teach him how to fly an airplane. Tódor Kármán’s first flight took place in Köln, with a Taube airplane. According to Kármán it was a good airplane type, it had only one fault: during landing it fell on its front easily. 


\section{The Great War}

In 1914, on an autumn day, Kármán received an official letter in which he was ordered to offer his services to the artillery. He was entrusted to determine the type of artillery necessary for the protection of Budapest, in case Russian soldiers would attack the city. Later the minister of war sent for him from Vienna where he was informed about further plans. Not far from Vienna, in the city of Fischamend an enormous airport was built, Kármán was sent there, where they wanted to establish a zeppelin hangar, but on Kármán’s proposal an experimental laboratory was built instead. In the frame of his next commission he had to design the aircraft with machine guns, which can fire between the shovels of the rotating propeller. In France, Roland Garros had a method for this design. One day, when they were testing the machine guns, there was an accident; the propeller broke and the pilot fell in German territory. The pilot was captured before he could destroy the airplane. The seized machine was handed to Anthony Fokker, a Dutch engineer, who found the fault in the machine gun and repaired it. According to Kármán, the improvement of the rocket-propelled fighter was the result of synchronized machine guns. During the joint work Kármán and Fokker became friends. In 1917, Kármán participated in helicopter experiments. The aim was to replace the air balloons used for monitoring, because they supposed that the helicopter would be safer. Together with Zsurovecz and Asbóth they developed the "bound helicopter".

It was bound because it was fixed to the ground with three ropes for its stability. It had two propellers, which rotated in opposite directions. The weight of their most famous model was 200 kilograms, operated by 3 engines with 120 horsepower each. They signed a contract with the Lipták factory in Budapest to carry out the production of the helicopters.

Kármán was asked to modify his helicopter to be suitable for the transport of supplies, should Berlin would be besieged and surrounded by hostile soldiers. Although he tried to explain to the German leaders that the helicopter could not be improved quickly enough at that time to meet these expectations, he was ordered to find a solution. He travelled back to Aachen in 1919. In accordance with the Peace Treaty of Versailles, the production of engine-driven airplanes was forbidden at that time. However, they could not suppress the inquiry of some students, who founded the student circle named as the Association of Aeronautical Science in Aachen. They sought out Kármán with the request to help them to build sailplanes. Airplane building fever swept amongst the students quickly. By 1920, the Schwarzer Teufel, the aircraft of the students of Aachen was built. Their next machine, Blaue Maus (in English: Blue Mouse) was completed in 1921. The machine flew for 13 minutes which beat the world record at that time. Hugo Junkers asked Kármán to be his advisor. In 1924 Tódor Kármán was invited to Zeppelin Works located next to the Lake Constance. The ship was completed in 1924, it left Germany in the autumn and reached its destination in New Jersey in 4 days, after 7830 kilometers.

\section{The United States and Asia}

In 1926, Tódor Kármán received a telegraph from Dr. Robert Millikan, Head of the California Institute of Technology, asking him to visit him in the United States, so as to help him to establish an aerodynamic laboratory. At the same time Kármán also got an invitation from Japan to assist in the formation of an aeronautical lab. Robert Andrews Millikan took over the leadership of Cal Tech in 1922. By the time Kármán arrived in 1926, two juveniles, Clark Millikan and Arthur Klein had already been working on the planned wind tunnel. The aim was to create an Eiffel-like wind tunnel, but Kármán suggested a more effective idea. The plans of the laboratory were completed by the autumn of 1926. Tódor Kálmán arrived in Jokohama. They asked Kármán to construct a wind tunnel and give lectures to their engineers. They finished building the wind tunnel by 1928 . In this year they started to produce their own airplanes in the Kawanishi Engineering Works.

Nationalism was spreading increasingly in Germany. Although Kármán liked his life in Aachen, he was uncertain about staying, thus between 1931 and 1932 he was commuting between Germany and Pasadena. Eventually, in 1933, he was warned to return or to renounce his position. Kármán chose Cal Tech after all.

In 1937, Frank Wattendorf, who was the Head of the Chinese Tsinghua University at that time, invited Kármán to Beijing. At the same time a Russian engineer also requested a visit from Kármán to Moscow. In the summer of 1937 Kármán left Russia to continue his journey to Manchuria.

Wattendorf waited for him in China, from the boarder they travelled together to Beijing. The 
Chinese aircraft fleet consisted of mainly American and Italian airplanes, but servicing these machines often caused a great intrigue to the Chinese technicians. They had already established an airplane factory before Kármán’s arrival; the following objective was the research department. Following Wattendorf's suggestion, they engaged in building a 5-6 meters wide and 70-100 meters long wind tunnel, which was designed and built by the Chinese students.

\section{Italy: The $5^{\text {th }}$ Volta Conference}

This was the first important event in the possibility of supersonic aeronautics. The greatest nations of the world appeared at the conference, among others the Soviet Union, Kármán was first interested in supersonic phenomena in 1908, and then he also wrote an essay about "the impulses arise in the convection that has higher speed than sound". In 1931, in Pasadena, he started to examine more seriously "the supersonic convection around bullets”. He regarded the bullets as small airships. With the contribution of one of Kármán's PhD students, Norton Moore, he published a study in 1932 in the topic of aerodynamics. In 1939, the leader of the Army Air Corps, Henry Arnold asked Tódor Kármán's advice about how they could make progress in aviation. Kármán recommended investing in a supersonic wind tunnel. Arnold took the advice, thus Kármán and Wattendorf started to design the wind tunnel. The high-speed wind tunnel was built in Aberdeen as a result.

The airplane factories in the United States began to build machines that approached supersonic speed in 1940.

\section{Rocketry}

In 1936, three juveniles visited Kármán, John W. Parsons, Frank Malina and Edward S. Forman, who wanted to make an interplanetary rocket. The intention was to build a rocket, which could be sent up to the height air balloons could not reach. In 1939, the Guggenheim Aeronautical Laboratory was established in the Cal Tech, where the first rocket experiment of the United States took place. The laboratory was renamed Jet Propulsion Laboratory later in 1944. It is the institute where Antal Bejczy had worked for 32 years, from 1937 until his retirement. The Ercoupe airplane was the most suitable for rocket experiments. In 1941, the first test flight took place. The JATO, the airplane equipped with the

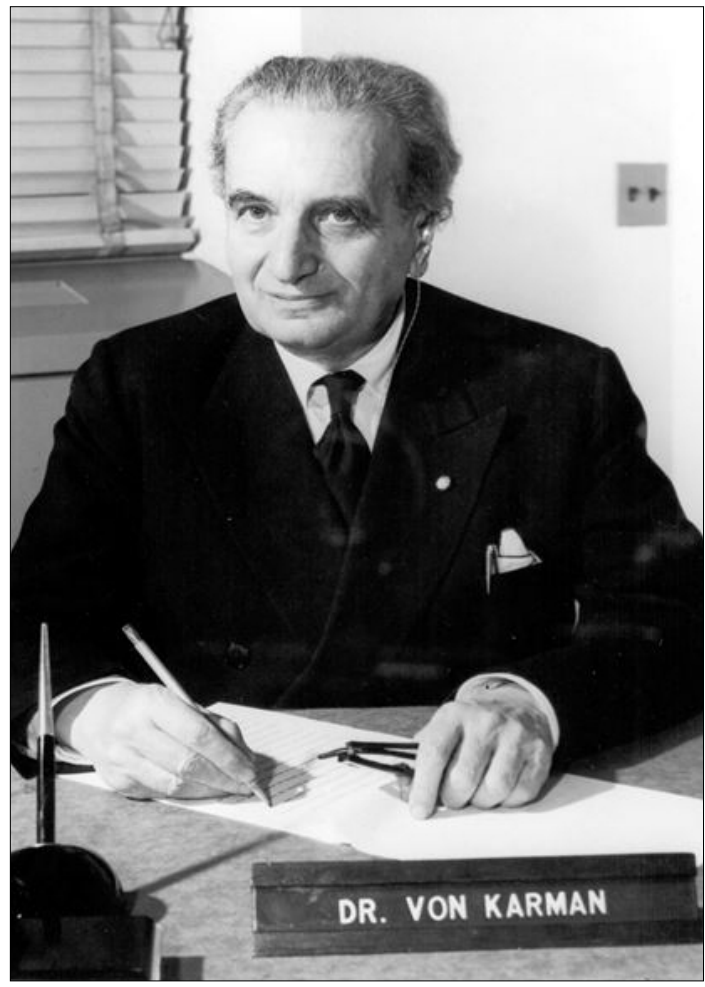

Figure 2. Tódor Kármán in his office

rocket helping the ascent proved itself; the rocket decreased the route of the ascent. In 1945, the end of the war was nearer. General Henry Arnold recommended a trip to Germany, in order to observe how far the Germans had got with their research. Not far from Braunschweig, the soldiers found an unknown, secret laboratory. Kármán and the group of the researchers travelled there to examine the institute.

After his return General Arnold asked Kármán to write a report about what he had seen in Germany, the title of the report was "Where We Stand". Kármán felt that he had not learned enough about the experiments of the Germans, so he travelled back to Europe. After he had learned all the information he needed, with Tódor Kármán’s contribution the study called "Towards New Horizons” was published. In 1947, Stuart Symington became the minister of the US Air Force. He supported Kármán's suggestion that is the air force needed a new research institute where they could examine and improve jet propulsion, supersonic airplanes and ballistic guided missiles. The institute - The Arnold Engineering Development Center - was established in Tullahoma, it was inaugurated by President Harry S. Truman in 1952. In 


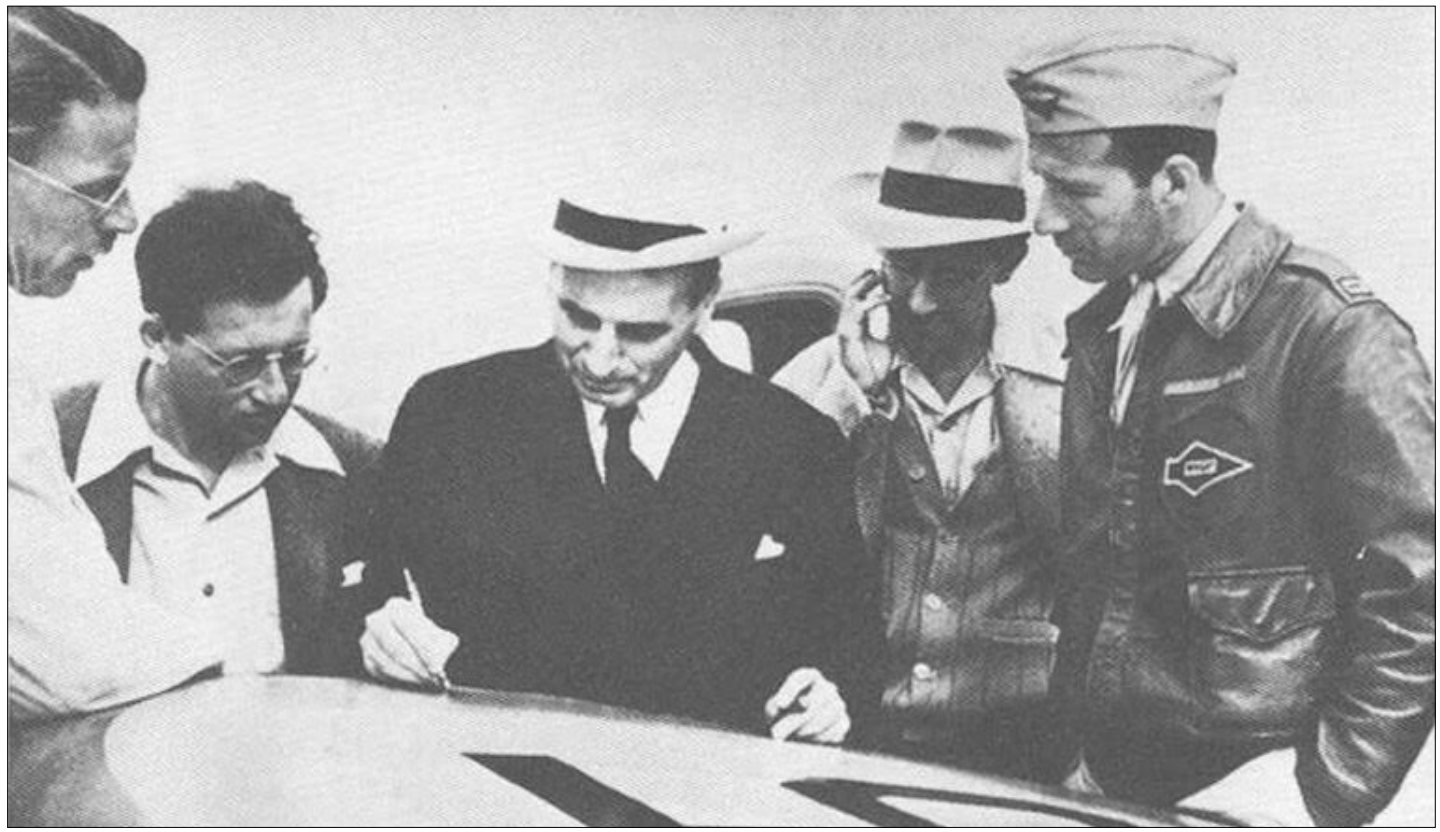

Figure 3 Tódor Kármán makes calculations on the wings of Ercoupe

1953, Tódor Kármán founded his scientific community, and he appointed János Neumann as his president. The members of the community were, among others, Ede Teller, Herbert Scoville and George Kistiakowsky.

In the 1950s Tódor Kármán was already in his seventies, but he still participated actively in scientific life, he was advisor of several aeronautical and astronautical companies. In 1962, the Aerojet had been formed 20 years. He went to Budapest in the autumn of 1962 for the last time and was bestowed with an Honorary Doctorate at the Budapest University of Technology and Economics. On the $22^{\text {nd }}$ October he held a lecture and met his followers at the Association of Technical and Natural Sciences Societies. The most important matter that his audience realized was that the scholar who left his homeland 40 years ago spoke his mother tongue perfectly and elaborately even that day, and without any accent.

Tódor Kármán died on 7h May, 1963, in Aachen.

\section{The Recollection of Tódor Kármán}

On the Moon $\left(45^{\circ} \mathrm{S}, 175^{\circ} \mathrm{E}\right)$ and on the Mars $\left(46,5^{\circ} \mathrm{S}, 59^{\circ} \mathrm{E}\right)$ there are craters, which are named as his honour, as well as one of the dormitories of the Budapest University of Technology and Economics for the mechanical engineers and the Tódor Kármán Prize with which the outstanding results in adult education and scientific research are awarded. The Hungarian Post published a stamp in his memory in 1992. On 23 ${ }^{\text {rd }}$ August, 1989, a memorial tablet was placed on Kármán’s childhood home in Szenkirályi Street, in Budapest. As a sign of their affection the Paks Nuclear Power Plant Ltd. commissioned a bust statue in park of the corporation in his memory, in 2004, which was made by the sculptor Pál Farkas. In addition, there is a statue of him in the Hungarian Technical and Transportation Museum.

\section{References}

[1] Lee Edson: Örvények és repülők - Kármán Tódor élete és munkássága. Akadémiai Kiadó, Budapest, 1994.

[2] Bödők Zsigmond: Magyar feltalálók a repülés történetében.

[3] Hargittai István: Az öt világformáló marslakó.

[4] Szentesi György: Kármán Tódor és a rakétatechnika. Fizikai szemle 2002/6.

[5] Peter L. Jakab: Kármán Tódor és a modern repülési-ürkutatási technika kialakulása. Fizikai szemle 1997/3.

[6] Almár Iván: Kármán és az ürhajózás. Fizikai szemle 2002/6.

[7] Szabó Edit: Bejczy Antal - Az ürrobotika atyja. Fizikai szemle 2001/11.

[8] Marx György: A marslakók legendája. In. Természettudományi és tudománytörténeti dokumentumok. Nagy magyar tudósok. (Eds.: Borbás J., Király P., Kőrösi M., Szalay I., Vámos J., Zimányi M.), Budapest, 1997. 